\title{
Unilateral testicular microlithiasis: a rare paediatric incidental finding
}

\author{
Bhargavi Kola
}

TTUHSC, Odessa, Texas, USA

\section{Correspondence to Dr Bhargavi Kola,} bhargavi.kola@ttuhsc.edu

Accepted 27 August 2016
CrossMark

To cite: Kola B. BMJ Case Rep Published online: [please include Day Month Year] doi:10.1136/bcr-2016216631

\section{DESCRIPTION}

A 9-year-old, African-American boy presented to his sports physical examination. He had no concerns or symptoms on the day of examination. His physical examination was remarkable for abnormal weight gain (body mass index $>90 \%$ for age and gender) and left undescended testis. He had an accidental injury and discomfort to his private area 4 months ago. His father had undescended testis but no testicular malignancy. Owing to concerns of trauma, a scrotal ultrasound was ordered that revealed interesting findings of multiple calcifications consistent with microlithiasis within the right testis (figures 1 and 2) and confirmed our diagnosis of left undescended testis. Testicular microlithiasis (TM) refers to the accumulation of many small calcifications within the seminiferous tubules and can be associated with malignant disorders of testis. ${ }^{1}$ They are usually impalpable and painless. ${ }^{1}$ Aetiology is unknown but possible theories include liquefaction of a spermatocyte's dendritus or consolidation of colloids in the testes. They are usually detected on incidental ultrasound (as in our case) and more commonly noted in adult males. Association with fragile $\mathrm{X}$ syndrome, downs syndrome and Kleinfelter syndrome could be indication of degenerative process. With regards to treatment, the condition itself is largely asymptomatic and resolves spontaneously, with degeneration of seminiferous tubules which questions the malignant transformation, but few cases have been reported to be associated with testicular malignancy in the past. ${ }^{2}{ }^{3}$ Although some cases of TM have been followed with serial ultrasounds, the recent recommendations suggest good surveillance with clinical follow-up and self-testicular examinations ${ }^{2}$ in a patient with no associated risk factors. Owing to the lack of clear guidelines for paediatric patients with TM and cryptorchidism, we will continue to

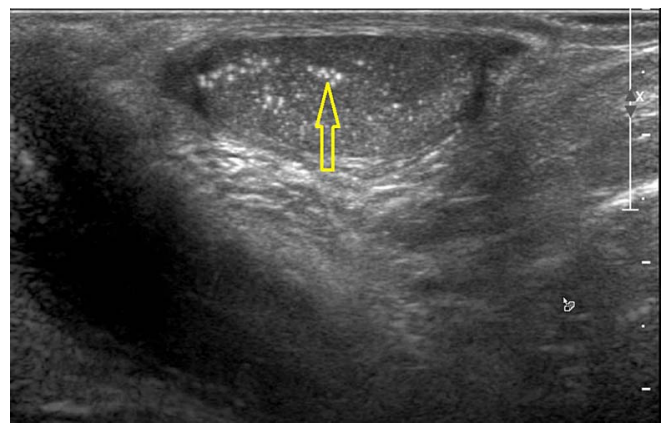

Figure 1 An ultrasound image showing multiple microcalcifications within the right testes consistent with microliths (yellow arrow).

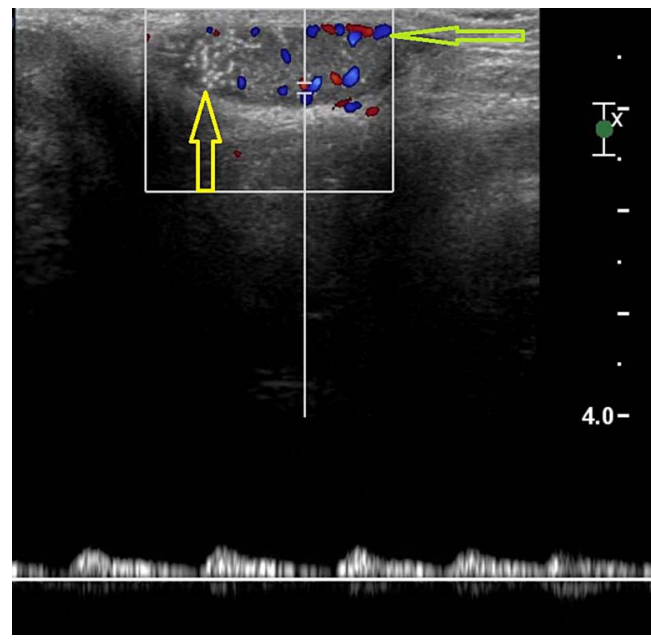

Figure 2 Ultrasound image showing normal arterial flow (green arrow) alongside multiple microliths (yellow arrow) within the right testes.

follow our patient closely with clinical examinations and yearly ultrasound examinations.

\section{Learning points}

- Testicular microlithiasis is a rare benign clinical condition that often times presents asymptomatically and diagnosed incidentally.

- Follow-up may be needed based on the associated risk factors like family history of testicular malignancy and other degenerative conditions.

- It is important for a clinician to thoroughly investigate and reassure patients and avoid unnecessary anxiety.

Competing interests None declared.

Patient consent Obtained.

Provenance and peer review Not commissioned; externally peer reviewed.

\section{REFERENCES}

1 Yesil S, Tanyildiz HG, Sahin G. How should we monitor boys with testicular microlithiasis? Pediatr Hematol Oncol 2016;33:171-7.

2 Chiang LW, Yap TL, Asiri MM, et al. Implications of incidental finding of testicular microlithiasis in paediatric patients. J Pediatric Urol 2012;8:162-5.

3 Konstantinos S, Alevizos A, Anargiros M, et al. Association between testicular microlithiasis, testicular cancer, cryptorchidism and history of ascending testis. Int Brazl J Urol 2006;32:43-8; discussion 439 
Copyright 2016 BMJ Publishing Group. All rights reserved. For permission to reuse any of this content visit http://group.bmj.com/group/rights-licensing/permissions.

BMJ Case Report Fellows may re-use this article for personal use and teaching without any further permission.

Become a Fellow of BMJ Case Reports today and you can:

- Submit as many cases as you like

- Enjoy fast sympathetic peer review and rapid publication of accepted articles

- Access all the published articles

- Re-use any of the published material for personal use and teaching without further permission

For information on Institutional Fellowships contact consortiasales@bmjgroup.com

Visit casereports.bmj.com for more articles like this and to become a Fellow 